\title{
POLITICAL TRADITION AND LOCAL SELF-GOVERNMENT IN RUSSIA ${ }^{1}$
}

\begin{abstract}
The article analyzes the most significant and persistent features of local self-government in Russia over the last three hundred years. It is emphasized that the first forms of territorial self-government developed only in the course of the reforms of the second half of the 19 century. The central government despite concerns of the country's disintegration had to tolerate self-government because government officials were unable to control the vast territories of the country. The lack of a clear division of powers between the state authorities and local government as well as unstable sources of funding for local representative bodies made them inevitably dependent of the central government. Therefore, the problem of achieving real autonomy of local government structures in the current municipal reform is still relevant.
\end{abstract}

Keywords: local territorial self-government; Russia; zemstvos; Soviets; municipalization.

\section{Introduction}

One of the most striking contradictions in the Russian civilization is the symbiosis of strong central power with a long-standing tradition of local self-government. This combination may be explained by the necessity to control vast and unevenly populated territories, which persisted through all the changes of central government's relation to local representative institutions.

Let us take a closer look at the core aspects of Russian local self-government to understand the patterns of its historical development.

1 The research was supported by the Russian Science Foundation (project number 16-18-10106). 


\section{Evolution of the main forms of local self-government}

The history of local self-government in Russia comprises four main stages:

1. The institutions of communal (corporate) self-government were the first to evolve. There is a popular view that they were related to social estates of the realm (soslovie), although it is still not quite clear when social estates actually appeared in Russia. Peasant communal self-organization, which relied on the same principles as urban communities, is particularly worthy of attention. The reforms of Peter I and Catherine II in the eighteenth century established representative institutions for the gentry and for merchants (merchant guilds), in addition to peasant and urban communities. According to V.V. Zhuravlev, between the eighteenth and the twentieth centuries all social groups in Russia had their self-government prerogatives ${ }^{2}$. A distinctive characteristic of these self-government bodies was that they served the interests of specific social groups rather than specific areas.

2. Zemstva appeared in 1864, when Russia was going through the crisis of its social hierarchy system. They were the first forms of territorial classless self-government and reflected the values of the developing bourgeois society. Although zemstva had to deal with some serious challenges and attracted a lot of criticism, this form of self-government deserves close attention.

3. Chronologically, the next to come were the soviets, which emerged after the Bolshevik seizure of power and existed until the collapse of the USSR. Despite the democratic principles that were declared at that time, this type of self-government definitely meant a retrograde step since the soviets were kept under close supervision of the central government. On the other hand, the soviets were organized according to the class model, which fitted well with the long-held concept of collective socially-orientated self-government of the communal type and legitimized the soviets in the eyes of the population ${ }^{3}$. Since soviets were supposed to be "workers' councils» and thus to represent the whole working population, this rendered irrelevant the question of local self-representation of different groups.

2 V.N. Zakharov (ed.), Territory and Power in Modern and Recent History of the Russian State, Moscow 2012, p. 390.

3 Until the consolidation of selsoviets (rural councils) in the first half of the 1920s, selsoviets and communities often coincided territorially (V.N. Zakharov, Territory and Power in Modern and Recent History of the Russian State, pp. 146, 190). 
4. Modern municipal self-government began as an attempt to adjust the Europeanized democratic model to Russian conditions. It was introduced by the legislation of the 1980-1990s while its key parameters were determined by the 1993 Constitution and the Federal Law No. 131 of 6 October 2003 'On the General Principles of the Organization of Local Government in the Russian Federation'4.

\section{Local self-government and state government bodies}

Another important question to discuss is the relations between local self-government and the structures of central and regional government. Most researchers believe that even autonomous local self-government cannot be considered as fully separated from the state and the state power5.

In Russia, the government has traditionally been highly centralized and followed the trends that can be traced back throughout the country's history:

1. The central government had to tolerate developed self-government because it dealt with such difficult issues as poverty and road building. However hard they tried, government officials were unable to control the vast territories of the country and had to delegate authority to lower self-organized structures.

2. Such distribution of authority inevitably engendered concerns about the country's disintegration (we can compare this situation to re-establishment of local self-government in Poland in the late 1980s ${ }^{6}$ ). Eventually, the central government tried to use direct administrative control or representatives of loyal social groups (for example, the gentry in zemstva or Party members in local soviets). Sometimes the government engaged to this end civil servants who combined their positions in regional and municipal administrations.

3. Bodies of local self-government cannot avoid being included in the power vertical, which deprives them of their autonomy even though their independence is asserted by the current legislation.

$4 \quad$ Federal Law of 06.10.2003, 131-Ф3 (version of 15.02.2016) 'On the General Principles of the Organization of Local Government in the Russian Federation', Consultant Plus, http:// www.consultant.ru/document/cons_doc_LAW_44571/(last accessed 23 May 2016).

5 See: R.F. Turovsky, Political and Regional Studies, Moscow 2006, p. 277.

6 J. Regulski, Self-Government in Poland, 'Novaya Polsha', http://archive.novpol.org/index. php?id=1795 (last accessed 23 May 2016). 


\section{Functions of local self-government}

The early forms of local self-government, for example, peasant communities, performed a wide range of functions but the increasing pressure of the state government gradually restricted the powers of communal democracy. In the eighteenth - early twentieth centuries, local self-government tended to perform more or less the same functions: fiscal, judicial, and recruiting. It was also responsible for providing its area with public services and amenities ${ }^{7}$. The central government was keen to delegate the duties of building and maintaining roads to peasant and urban communities. With the introduction of universal military service, the recruiting function became no longer necessary but the fiscal function was preserved until the early 1930s (while some part of the population was still financially independent from the state). Throughout their history, institutions of self-government were responsible for providing welfare services to the local population.

Since local governments were chronically afflicted with deficit of power and many regions were remote from the centre, local officials (elected or appointed) were trying to broaden their powers, which made the state distrustful of grassroots public activity. Bodies of local self-government started to compete with state officials, which created a threat of disintegration and forced the central government to take countermeasures restricting the authority of elected bodies. Thus, Russian history offers us a tough choice: we can either have a strong state or strong local self-government, which makes the problem of administrative balance particularly important even to the present day.

Trying not to lose control, the state deliberately avoided delineating powers between the regional authorities and local self-government bodies. State agencies duplicated the powers of self-government: this trend was observed in statehouses of the Petrine era; in the nineteenth-century zemstva and urban self-government institutions; and in modern municipalities. As for the soviets, their functions were duplicated by the corresponding Party structures.

7 For more detail see: B.N. Mironov, Russian Empire: from Traditions to Modernity, vol. 2, St. Petersburg 2015, pp. 152-156. 


\section{Levels of local representative democracy}

Historically, the grassroots local representation (rural or urban communities) was the most stable because it satisfied the interests of specific social groups. In the eighteenth and nineteenth centuries the government used communal or guild representation to create structures of volost and urban self-government, which belonged to the state government system and thus were the agents of state power.

Higher levels of self-government were classless and therefore up until a certain point they were difficult to realize in Russia. The first classless institutions were zemstva, which emerged at the stage of industrial modernization and operated on the levels of uezds and guberniyas. The government had to eliminate the peasant community in order to make zemstva more powerful and to establish volost zemstva. In the early twentieth century Petr Stolypin made such an attempt but without much success.

Centralized classless representation could have strengthened the tradition of zemstva but the Imperial Duma convened in 1906 could not compete with the autocratic monarchical power.

Thus, the pre-Soviet system of local self-government had a pyramid-like structure: while the state dominated the top of this pyramid, its base provided the population with more opportunities for self-organization.

The soviets demonstrated a similar trend: the lower soviets (rural, urban and district), which regulated the life of specific areas, created pre-conditions for the process of modern municipalization while the soviets of higher levels did the same for federalization.

Municipalities are a modern form of self-government in Russian, traditionally existing on the regional and urban levels.

\section{Economic autonomy of local self-government}

Any form of power depends on funds and resources. Historically, peasant communities had limited powers not only because they faced administrative restrictions but also because they were short of resources. The same happened to most local gentry organizations in the second half of the nineteenth century, when their scarcity of funds resulted in the loss of power ${ }^{8}$.

$8 \quad$ V.N. Zakharov (ed.), Territory and Power..., p. 82. 
After the zemstva were established as the first real territorial institutions of self-government, an attempt was made to demarcate the sources of tax revenues for different levels of power. Apart from the special zemstvo tax, zemstva also received revenues from property taxation in towns and uezds. Zemstvo funding, however, was far from being stable. According to N. G. Koroleva, the anarchy in taxation was always the scourge of zemstva funding. It also negatively affected the relations between zemstva of uezds and those of guberniyas ${ }^{9}$.

The government took conscious efforts to maintain this kind of uncertainty: in the War Communism period, the government supported the authority of local soviets by delegating them administrative and distributive functions, at the same time ignoring zemstva, which still persisted. In the NEP years, the government returned to the archaic form of funding local soviets through 'self-taxation' of peasants ${ }^{10}$. Funding became more regular and centralized during the collectivization, after the soviets had been completely dissociated from rural communities.

According to the current law on local self-government, the main sources of municipal funding are the land tax and the personal property tax. According to D.V. Maslov, however, these taxes account only for $12 \%$ of the municipal budget revenues, which means that the central government continues to create the situation of financial uncertainty in order to preserve its control over municipal bodies ${ }^{11}$.

\section{Conclusion}

Taking into consideration all the above-discussed characteristics, we can conclude that there is a specifically Russian model of local self-government, which is subject to tight governmental control and is embedded into the vertical structure of power. Nevertheless, there is a hope that this kind of local self-government will gradually obtain more autonomy, for example, through the development of small and medium business, which will mean the expansion of the local taxable base.

9 N.G. Koroleva, Zemstvo in Transition (1905-1907), Moscow 1995, pp. 27-28.

10 This means that selsoviets were expected to conduct general meetings and take the decision to collect money from the population similar to the way as it had been done in the peasant community.

11 V.N. Zakharov (ed.), Territory and Power..., p. 277. 
Another prerequisite for achieving the optimal balance between the state and the society is to alleviate the bureaucratic pressure on municipalities and make them more autonomous, which has been declared as one of the targets of the ongoing municipal reform. However, it is still hard to tell whether in these conditions Russian institutions of self-government will manage to gain any real independence.

\section{Literature}

1. Koroleva N.G., Zemstvo in Transition (1905-1907), IRI RAN, Moscow 1995.

2. Mironov B.N., Russian Empire: from Traditions to Modernit, vol. 2, Dmitry Bulanin, St. Petersburg 2015.

3. Regulski J., Self-Government in Poland, 'Novaya Polsha', http://archive.novpol.org/index. php?id=1795 (last accessed 23 May 2016).

4. Turovsky R.F., Political and Regional Studies, Higher School of Economics, Moscow 2006.

5. Zakharov V.N. (ed.), Territory and Power in Modern and Recent History of the Russian State, ROSSPEN, Moscow 2012.

Oleg Gorbachev

Ural Federal University 